\title{
SKIN TEMPERATURES OF THE EXTREMITIES OF PERSONS WITH INDUCED DEFICIENCIES OF THIAMINE, RIBOFLAVIN, AND OTHER COMPONENTS OF THE B COMPLEX
}

\author{
By GRACE M. ROTH, R. D. WILLIAMS, AND CHARLES SHEARD \\ (From the Section on Clinical Physiology, Mayo Clinic; the Department of Medicine, Mayo Founda- \\ tion, and the Division of Physics and Biophysical Research, Mayo Clinic and Mayo \\ Foundation, Rochester, Minnesota)
}

(Received for publication January 3, 1944)

Disturbances of vasomotor responses of the feet have been reported by Wenckebach (1), Weiss and Wilkins (2), and Wilkins and Kolb (3) among patients suffering with peripheral neuritis, associated with vitamin deficiency. The latter investigators stated that the disturbance was characterized by a decrease of the vasomotor tonus of the feet, resembling that found after resection of the first and second lumbar sympathetic ganglia. The vasoconstrictor response, as recorded by the plethysmograph, to brief vasoconstrictor stimuli was slight in the toes as compared with the fingers. Also, measurements of skin temperature showed that the toes were constantly warmer than the fingers; this was even more pronounced when the patients were subjected to a cool environment. After the body had been warmed, the skin temperature of the toes rose slightly or remained unchanged while the skin temperature of the fingers rose to or above that of the toes.

Since clinical and chemical studies of induced deficiency of thiamine, riboflavin, and other components of the $B$ complex in human subjects were being carried out by Wilder, Mason, Cusick, Power and one of us (Williams) (4 to 6), the present studies were made in conjunction with these controlled studies to determine the amount of vasomotor disturbance in the extremities by means of measurements of skin temperature. Measurements of the loss of vasomotor tonus were made and correlated with the clinical signs and symptoms of deficiency disease, the apparent degree of depletion of the tissue stores of vitamins, and the severity of the metabolic defect.

\section{METHODS OF STUDY}

Selection of subjects. The studies were made on 8 physically healthy women from the nutrition division of the Rochester State Hospital. Their ages ranged from 25 to 48 years. During the period preliminary to restriction of the vitamins, the subjects were provided with an ample diet and daily supplements of $2.0 \mathrm{mgm}$. each of thiamine, of riboflavin, and of pyridoxine, $5.0 \mathrm{mgm}$. of calcium pantothenate, and $\mathbf{4 0 . 0} \mathrm{mgm}$. of nicotinamide for several weeks, so that a good status of nutrition could be assured prior to the restriction of the various vitamins.

The 8 subjects were divided into 4 groups of 2 subjects each and observations were made on (1) severe isolated restriction of thiamine hydrochloride, (2) the effects of thiamine deficiency on induced hyperthyroidism, (3) isolated restriction of riboflavin, and (4) restriction of the vitamin B complex.

Methods of observation. Physical and neurological examinations and electrocardiograms had been made and basal metabolic rates had been determined in the period of preliminary observation; these tests were repeated at intervals in the period of restriction of intake of vitamins and again in a subsequent period when adequate amounts of vitamins were provided. Criteria for determining the degree of depletion of vitamins were as follows: 1. Determinations of tissue stores of vitamins. We determined the "ordinary" excretions of thiamine and riboflavin in 24 hours, the subject receiving a measured amount of these vitamins in the diet. We also determined excretion of thiamine and riboflavin in the urine in 4 hours after subcutaneous injection of $1.0 \mathrm{mgm}$. of thiamine hydrochloride and $2.0 \mathrm{mgm}$. of sodium riboflavin, the subject being in the postabsorptive state. Excretions of thiamine and riboflavin are suggestive indexes of tissue store of these vitamins. 2. Determination of biochemical status of tissues. The levels of pyruvic acid and lactic acid in the blood after administration of dextrose are suggestive indices of biochemical status of tissue of the body. 3. Clinical status of the subject. Particular emphasis was placed on the development of objective signs of impairment of functions of the nervous system.

At various intervals, and more or less concomitantly with the other observations, the measurements of skin temperature were made in psychrometric rooms (7). The subjects had fasted for 15 hours prior to the tests and, during the time of testing, they wore light weight short pajamas and were in a supine position in comfortable beds. The temperatures of the plantar surfaces of the first and third toes of both feet and of the volar side of the distal phalanges 


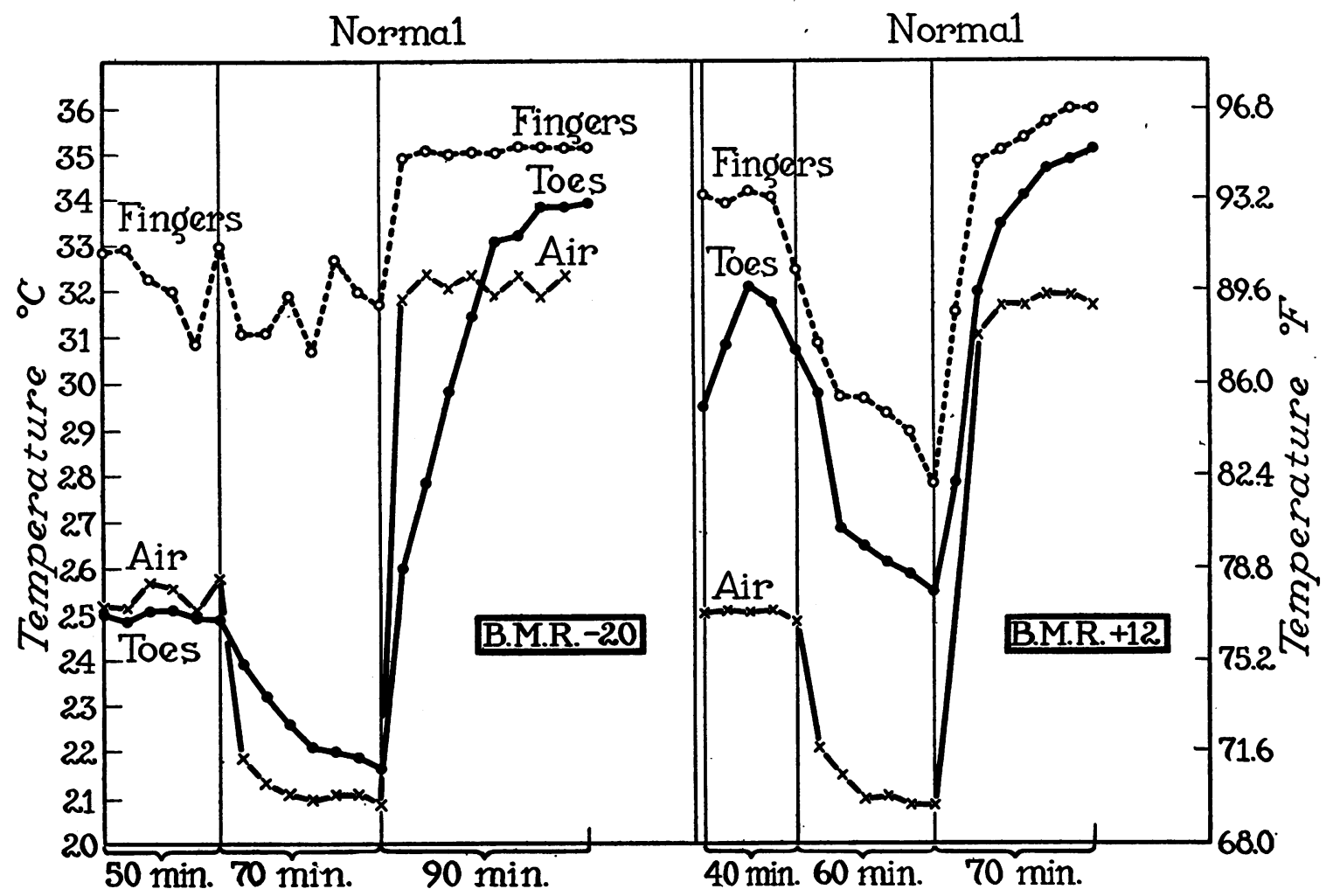

Fig. 1. Changes of Skin Temperature of the Fingers and Toes with Changes of Environmental Temperatures

Note the variation of skin temperature of the fingers and toes associated with a variation of basal metabolic rate.

of the first and third fingers of the two hands were measured by means of copper-constantan thermocouples.

Since it had been shown that there is an approximately linear relationship (8) (which, however, seems to be of a dual character) existing between the average skin temperature of the toes and the basal metabolic rates obtained under environmental conditions of $25^{\circ} \mathrm{C}$. $\left(77^{\circ} \mathrm{F}\right.$.) with a relative humidity of 40 per cent, basal metabolic rates were determined on the previous day or the day after the measurements of skin temperature had been made.

Further, in order to demonstrate more clearly a loss of vasomotor tonus, skin temperatures were measured upon moving the subjects from a comfortable to a cooler environment and later to a warmer environment. Changes which occur in normal subjects under such conditions are demonstrated in Figure 1. When a normal person had remained for an hour or more at an environmental temperature of $25.5^{\circ} \mathrm{C}$. $\left(78^{\circ} \mathrm{F}\right.$.) with a relative humidity of 40 per cent, fairly constant readings were obtained and these showed a definite correlation with the basal metabolic rate. When the normal person was moved to a cooler environment of $20^{\circ} \mathrm{C}$. $\left(68^{\circ} \mathrm{F}\right.$.), there was relatively little thermal change in the forehead, thorax, arms, and upper portion of the legs. In contrast, there was definite cooling of the toes, and constancy of temperature (approximately that of the room) was reached in about an hour, except for those subjects who had higher basal metabolic rates.
The amount of cooling is closely associated with the basal metabolic rate. In turn, when the subject was moved from a room at $20^{\circ} \mathrm{C}$. $\left(68^{\circ} \mathrm{F}\right.$.) to one of $32^{\circ} \mathrm{C}$. $\left(89.6^{\circ} \mathrm{F}\right.$. $)$, the changes of temperature were again most pronounced in the toes. The rise of temperature was rapid at first; this was followed by a gradual change as the temperature of the toes approximated a maximal value of about $35^{\circ} \mathrm{C}$. $\left(95^{\circ} \mathrm{F}\right.$.). The basal metabolic rate of the subject on the left (Figure 1) was -20 per cent, while that of the one on the right was +12 per cent.

In contrast, the loss of vasomotor tonus was demonstrated by observations following left lumbar sympathetic ganglionectomy and trunk resection, as is shown in Figure 2. The temperature of the toes on the left foot was approximately $35.0^{\circ} \mathrm{C}$., which was $3^{\circ}$ higher than the fingers, whereas the temperature of the toes on the right foot was approximately $27^{\circ} \mathrm{C}$. When the subject was moved to an environmental temperature of $20^{\circ} \mathrm{C}$. $\left(68^{\circ} \mathrm{F}\right.$.), marked vasoconstriction occurred in the fingers and toes of the right side but the toes of the left foot remained warm. On moving him to an environmental temperature of $30^{\circ} \mathrm{C}$. $\left(86^{\circ} \mathrm{F}\right.$.), the temperature of the toes of the left foot was not appreciably changed while a marked rise of the surface temperature of the fingers and toes of the right side occurred. It was this kind of response that Wilkins and Kolb (3) found in a large number of their patients suffer- 


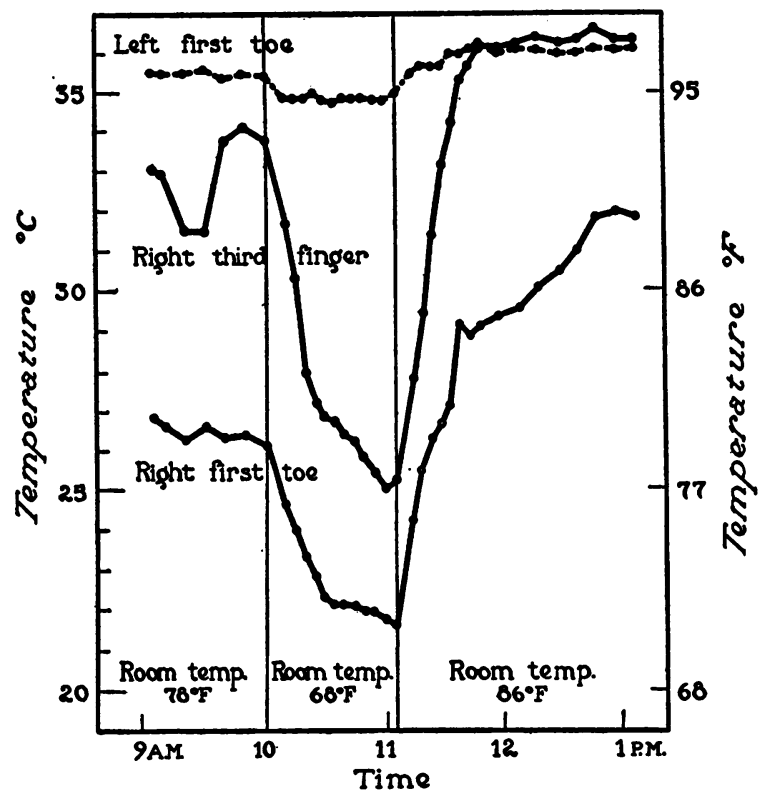

Fig. 2. Changes of Skin Temperature of the Fingers and Toes with Changes of Environmental Temperatures following Left Lumbar Sympathetic GaNglionectomy and TRUNK Resection

(From Horton, Sheard and Roth: Vasomotor regulation of the temperatures of the extremities in health and disease. J. M. Soc. New Jersey [June] 1940).

ing with peripheral neuritis associated with vitamin deficiency.

\section{RESULTS}

Group I. Severe isolated restriction of thiamine (Table $I$ ). The intake of thiamine of 2 subjects, aged 48 and 36 years, was restricted to $0.175 \mathrm{mgm}$. per 1000 calories. Data on the excretions of thiamine, the concentration of pyruvic acid and lactic acid in the blood after administration of dextrose, and the neurologic status are contained in another report (4). Briefly, at the end of 110 days of restriction of vitamins, the severity of the thiamine deficiency was grade 3 on a basis of 1 to 4. The excretion of thiamine in the urine was decreased to a level of 10 to 20 micrograms for 24 hours. There was marked elevation of the concentration of pyruvic acid and lactic acid after the administration of dextrose. The amplitude of all the complexes of the electrocardiogram, particularly of the $\mathrm{T}$ waves, of $\mathrm{CR}_{2}$ and IV $R$ was somewhat decreased and sinus bradycardia and arrhythmia were present. Neurologically, the deep reflexes were decreased or absent ( -3 to -4$)$, muscle strength was impaired ( -3$)$, and the ability to arise from a squatting position was decreased, but the subjects could still walk. Paresthesia was present.

At the end of 120 days of restriction of thiamine, there was marked progression of signs and symptoms to grade 4 . The excretion of thiamine was very low, the biochemical defect was severe, and a considerable degree of prostration was noted. The more severe neurologic defects occurred in subject 2, namely, paralysis of the quadriceps femoris and paresis of the other muscles of the legs. Perception of a wisp of cotton and pin point was diminished but not absent.

Following this period, subject 1 was given 0.22 mgm. of thiamine per 1000 calories daily for 58 days and then the dose was increased to $30 \mathrm{mgm}$. per 1000 calories for 37 days. At the end of this period, evidence of vitamin deficiency had disappeared except for a slight decrease of the deep reflexes. Subject 2 received $20 \mathrm{mgm}$. intravenously and $60 \mathrm{mgm}$. per 1000 calories, orally, for 31 days and then the daily intake was decreased to $15 \mathrm{mgm}$. per 1000 calories orally for 64 days. At the end of this time, weakness of the quadriceps femoris muscles was so great that she was unable to rise from a squatting position, and there was absence of the tendon reflexes of the legs. Figure 3 shows the measurements of skin temperature during the period of severest vitamin deficiency and after recovery from this deficiency. The curves of both subjects were practically the same; therefore, only one is presented. At the time when the thiamine deficiency was greatest, the basal metabolic rate was 0 per cent. Although there were a few transient changes of the basal metabolic rate during the period of recovery, at the time the measurements of skin temperature were made again, the basal metabolic rate was also 0 per cent. In both instances, vasoconstriction took place normally under the cool environment of $22^{\circ} \mathrm{C}$. $\left(71.6^{\circ} \mathrm{F}\right.$.) while vasodilatation followed on moving the subject to a hot environment of $32^{\circ} \mathrm{C}$. $\left(89.6^{\circ} \mathrm{F}\right.$.). This was indicated by a marked rise of the skin temperature of the toes. At no time were the toes warmer than the fingers.

Group II. Effects of thiamine deficiency on 
TABLE I

Severe isolated thiamine deficiency and recovery

1. A woman aged 48 years, weight $55 \mathrm{kgm}$., height $161 \mathrm{~cm}$.

2. A woman aged 36 years, weight $56.5 \mathrm{kgm}$., height $168 \mathrm{~cm}$.

\begin{tabular}{|c|c|c|c|c|c|c|c|c|}
\hline \multirow{2}{*}{ Number } & \multirow{2}{*}{ Intake } & \multirow{2}{*}{ Thiamine } & \multirow{2}{*}{$\begin{array}{c}\text { Basal } \\
\text { metabolic } \\
\text { rate }\end{array}$} & \multirow{2}{*}{$\begin{array}{l}\text { Bio- } \\
\text { chemical } \\
\text { defect }\end{array}$} & \multirow{2}{*}{$\begin{array}{l}\text { Abnormal } \\
\text { electro- } \\
\text { cardiogram }\end{array}$} & \multicolumn{3}{|c|}{ Neurologic findings, grade } \\
\hline & & & & & & $\underset{\text { Deep }}{\text { reflexes }}$ & $\begin{array}{c}\text { Muscle } \\
\text { strength }\end{array}$ & $\begin{array}{l}\text { Pares- } \\
\text { thesia }\end{array}$ \\
\hline \multirow[t]{6}{*}{1} & $\begin{array}{l}\text { days } \\
110\end{array}$ & $\begin{array}{l}\text { mgm. } \\
0.175^{*}\end{array}$ & $\begin{array}{l}\text { per cent } \\
\quad-5\end{array}$ & +3 & + & -3 to -4 & -3 & + \\
\hline & \multirow[t]{2}{*}{120} & \multirow[t]{2}{*}{$0.175^{*}$} & \multirow[t]{2}{*}{0} & \multirow[t]{2}{*}{+4} & \multirow[t]{2}{*}{+} & -3 to -4 & -4 & + \\
\hline & & & & & & \multicolumn{3}{|c|}{ Considerable prostration } \\
\hline & \multicolumn{8}{|c|}{ Period of treatment } \\
\hline & 58 & $0.220^{*}$ & -4 & +2 & 0 & -3 to -4 & -1 & 0 \\
\hline & 37 & $30.000^{*}$ & 0 & 0 & $\mathbf{0}$ & -1 to -2 & -1 & 0 \\
\hline \multirow[t]{8}{*}{2} & 110 & $0.175^{*}$ & -7 & +3 & + & -3 to -4 & -3 & + \\
\hline & \multirow[t]{2}{*}{120} & \multirow[t]{2}{*}{$0.175^{*}$} & \multirow[t]{2}{*}{-10} & \multirow[t]{2}{*}{+4} & \multirow[t]{2}{*}{+} & -4 & -4 & + \\
\hline & & & & & & \multicolumn{3}{|c|}{$\begin{array}{l}\text { Paralysis of quadriceps femoris; sensory } \\
\text { perception, grade }-2 \text { to light touch and } \\
\text { pain }\end{array}$} \\
\hline & \multicolumn{8}{|c|}{ Period of treatment } \\
\hline & \multirow[t]{2}{*}{31} & & \multirow[t]{2}{*}{+7} & \multirow[t]{2}{*}{+2} & \multirow[t]{2}{*}{0} & -4 & -4 & + \\
\hline & & $\begin{array}{l}60 \text { orally* } \\
20 \mathrm{I} . \mathrm{V} .\end{array}$ & & & & \multicolumn{3}{|c|}{$\begin{array}{l}\text { Inability to rise from squatting posi- } \\
\text { tion; no sensory disturbance }\end{array}$} \\
\hline & \multirow[t]{2}{*}{64} & \multirow{2}{*}{$\begin{array}{l}15.000 \\
\text { orally* }\end{array}$} & \multirow[t]{2}{*}{-10} & & \multirow[t]{2}{*}{0} & -4 & -2 & + \\
\hline & & & & & & \multicolumn{3}{|c|}{ Inability to rise from squatting position } \\
\hline
\end{tabular}

* Per 1,000 calories of daily diet.

induced hyperthyroidism. Since in earlier studies of moderate and prolonged deprivation of thiamine, in some instances, the basal metabolic rates of various subjects had been irregularly lowered and since a study was being carried out to determine the effectiveness of the thyroid hormone during periods of thiamine restriction, a second group of subjects was studied (Table II). The first of this group of subjects, who was aged 47 years, was given 0.6 grams (10 grains) of desiccated thyroid per day for a period of 185 days, and the second subject, aged 25 years, was given 0.5 grams (8 grains) of desiccated thyroid per day for the same period. The intake of thiamine was restricted to $0.45 \mathrm{mgm}$. per 1000 calories daily for a period of 108 days. Definite evidence of thiamine deficiency was present in both subjects at this time. The basal metabolic rate was increased to +19.1 per cent for the first subject and to +25.6 per cent for the second subject. Following this period, increasing amounts of thiamine were given over a period of 77 days. In spite of the increased intake of thiamine, definite evidence of vitamin deficiency was observed and was still present at the end of this time. In both subjects, there were muscle weakness and inability to rise from the squatting position. Apparently, the thyroid hormone was less effective for the maintenance of metabolic processes in states of thiamine deficiency than in the normal state, for concomitantly with the increase of intake of thiamine, the basal metabolic rates became higher. The skin temperature curves are shown in Figure 4. 


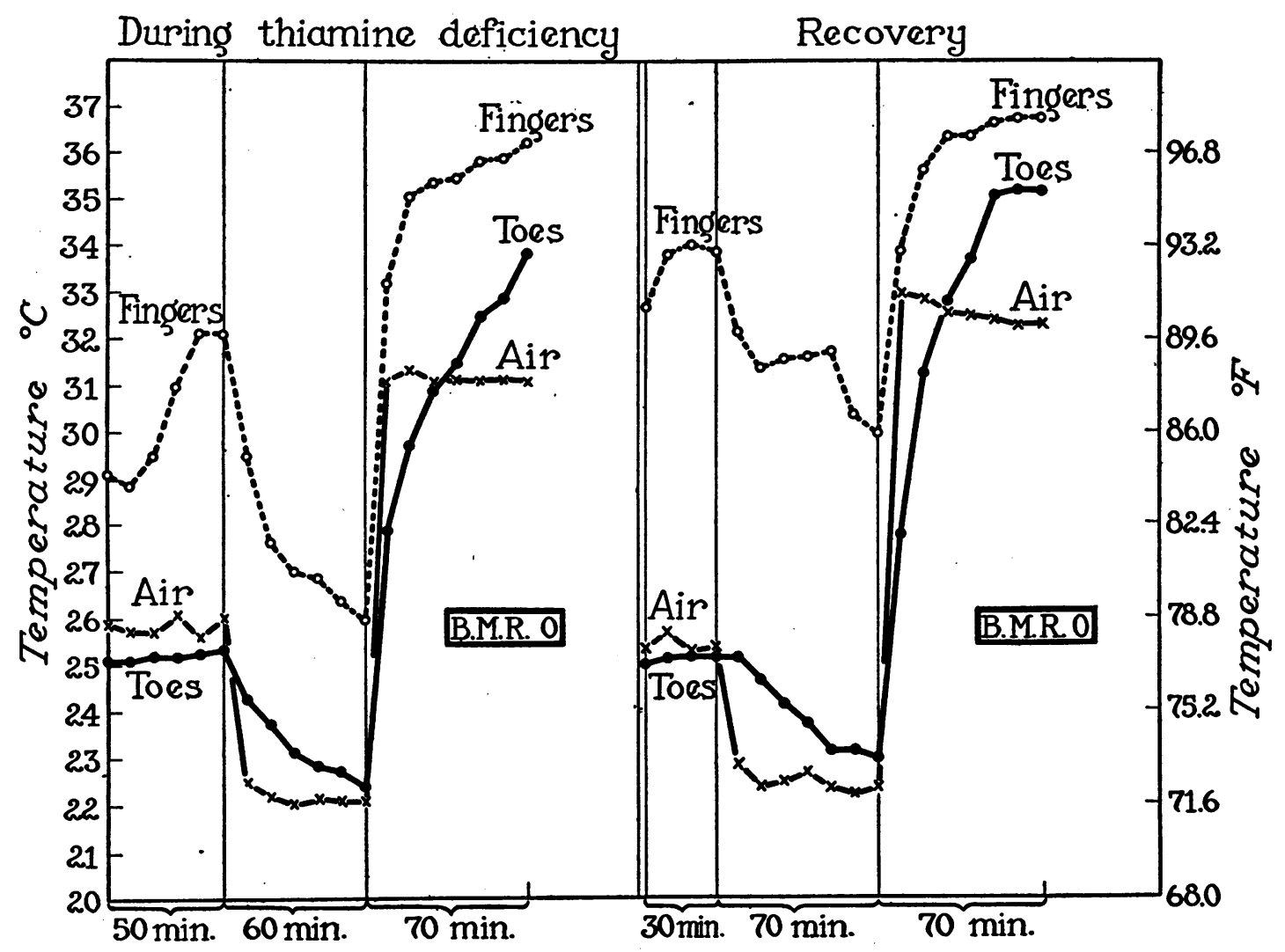

Fig. 3. A Comparison of the Changes of Skin Temperature of the Fingers and Toes with Changes of Environmental Temperatures During Thiamine Deficiency and Following Recovery from This Deficiency

Because the many skin temperature curves were similar, only one curve is shown. Again the correlation between the skin temperature of the toes and the basal metabolic rate was more evident than any correlation with known vitamin deficiency. In contrast, the skin temperatures of a patient who had hyperthyroidism without vitamin deficiency are shown. The basal metabolic rates were comparable and at no time did the skin temperature of the toes even approximate that of the fingers.

Group III. Isolated riboflavin deficiency. This group consisted of 2 subjects aged 42 and 32 years. They received an adequate diet except for riboflavin, which was restricted to $0.7 \mathrm{mgm}$. per day (0.35 mgm. per 1000 calories) over a period of 288 days. Data on the intake and excretions of riboflavin together with clinical observations have been reported (5). Briefly, the vitamin deficiency was demonstrated by unmistakable depletion of the tissue stores of riboflavin. The subjects had only occasional transient symptoms. The physical and neurologic examinations gave consistently negative results. The pyruvic acid and lactic acid levels were not elevated. The electrocardiograms and basal metabolic rates were unchanged. Ulceration, maceration, or excrescences at the corners of the mouth, at the nasolabial folds, beneath the pinna of the ears, or of any of the cutaneous folds were not observed. The tongue, the gums, and the vermilion border of the lips remained essentially normal. Measurements of skin temperature at various times during the period of restriction showed very little change. The skin temperatures of the toes showed more or less close correlation with the individual basal metabolic rates, which were little changed.

Group IV. Deficiency of the B complex. This group consisted of 2 subjects aged 44 and 30 years. The diet was deficient, so far as it could be judged, in vitamins of the B complex; it was 
TABLE II

Isolated thiamine deficiency and induced hyperthyroidism

1. A woman aged 47 years, height $172 \mathrm{~cm}$.

2. A woman aged 25 years, height $158 \mathrm{~cm}$.

\begin{tabular}{|c|c|c|c|c|c|c|c|c|}
\hline \multirow{2}{*}{ Number } & \multirow{2}{*}{ Intake } & \multirow{2}{*}{ Thiamine * } & \multirow{2}{*}{$\begin{array}{c}\text { Desic- } \\
\text { cated } \\
\text { thyroid }\end{array}$} & \multirow{2}{*}{$\begin{array}{c}\text { Basal } \\
\text { metabolic } \\
\text { rate }\end{array}$} & \multirow{2}{*}{$\begin{array}{c}\text { Bio- } \\
\text { chemical } \\
\text { defect }\end{array}$} & \multirow{2}{*}{$\begin{array}{l}\text { Abnormal } \\
\text { electro- } \\
\text { cardiogram }\end{array}$} & \multicolumn{2}{|c|}{ Neurologic findings, grade } \\
\hline & & & & & & & $\underset{\text { reflexes }}{\text { Deep }}$ & $\begin{array}{c}\text { Muscle } \\
\text { strength }\end{array}$ \\
\hline \multirow[t]{8}{*}{1} & $\begin{array}{l}\text { days } \\
103\end{array}$ & $\begin{array}{l}m g m . \\
0.45\end{array}$ & $\begin{array}{c}\text { grams } \\
0.6\end{array}$ & $\begin{array}{l}\text { per cent } \\
+15.4\end{array}$ & +4 & + & -1 to -2 & -2 \\
\hline & 5 & 0.45 & 0.6 & +19.1 & +4 & + & -1 to -2 & -2 \\
\hline & 19 & 0.75 & 0.6 & & +4 & + & -1 to -2 & -2 \\
\hline & 17 & 1.07 & 0.6 & & & & & \\
\hline & 15 & 1.55 & 0.6 & & & & & \\
\hline & 15 & 1.65 & 0.6 & & & & & \\
\hline & 11 & 15.00 & 0.6 & +28.3 & +4 & + & \multirow{2}{*}{\multicolumn{2}{|c|}{$\begin{array}{l}-4 \quad-3 \\
\text { Inability to rise from } \\
\text { squatting position }\end{array}$}} \\
\hline & $\begin{array}{l}\text { Total } \\
185\end{array}$ & & & & & & & \\
\hline \multirow[t]{8}{*}{2} & 103 & 0.45 & 0.5 & +24.3 & +4 & + & -1 to -2 & -2 \\
\hline & 5 & 0.45 & 0.5 & +25.6 & +4 & + & -1 to -2 & -2 \\
\hline & 19 & 0.75 & 0.5 & & & & & \\
\hline & 17 & 1.07 & 0.5 & & & & & \\
\hline & 15 & 1.55 & 0.5 & & & & & \\
\hline & 15 & 1.65 & 0.5 & & & & & \\
\hline & 11 & 15.00 & 0.5 & +28.0 & +4 & + & -4 & -3 \\
\hline & $\begin{array}{l}\text { Total } \\
185\end{array}$ & & & & & & \multicolumn{2}{|c|}{$\begin{array}{l}\text { Inability to rise from } \\
\text { squatting position }\end{array}$} \\
\hline
\end{tabular}

* Per 1,000 calories of daily diet.

known to be deficient in thiamine and riboflavin. Restriction took place over a period of 243 days. Data on intake and excretions of thiamine and riboflavin are contained in a separate report (6). Signs and symptoms of thiamine deficiency were evident in 100 days. At the end of 243 days, the excretion of thiamine and riboflavin was decreased, the pyruvic acid and lactic acid levels in the blood were abnormally elevated following the administration of dextrose, but there were no objective neurologic changes present. The skin temperatures were more closely associated with moderate changes of basal metabolic rates than with the state of vitamin deficiency.

These observations are in contrast to those found by Wilkins and Kolb (3). Their studies for the most part were made on patients who had peripheral neuropathy, associated with alcoholism. The degree of depletion of tissue stores of vitamins and the severity of biochemical defects were not determined. Undoubtedly, the nutritional deficiencies of these patients had extended over a long period and irreversible changes may have occurred. In our studies, the degree and duration of restriction of vitamins were known, biochemical defects were demonstrated, and both neurologic and other physical defects were observed to develop with restrictions of vitamins and to disappear with administration of crystalline vitamins. Effects of ingestion of toxic substances and incidence of infectious processes were excluded by the conditions of the experiment. 
Induced thiamine deficiency and induced hyperthyroidism

Hyperthyroidism

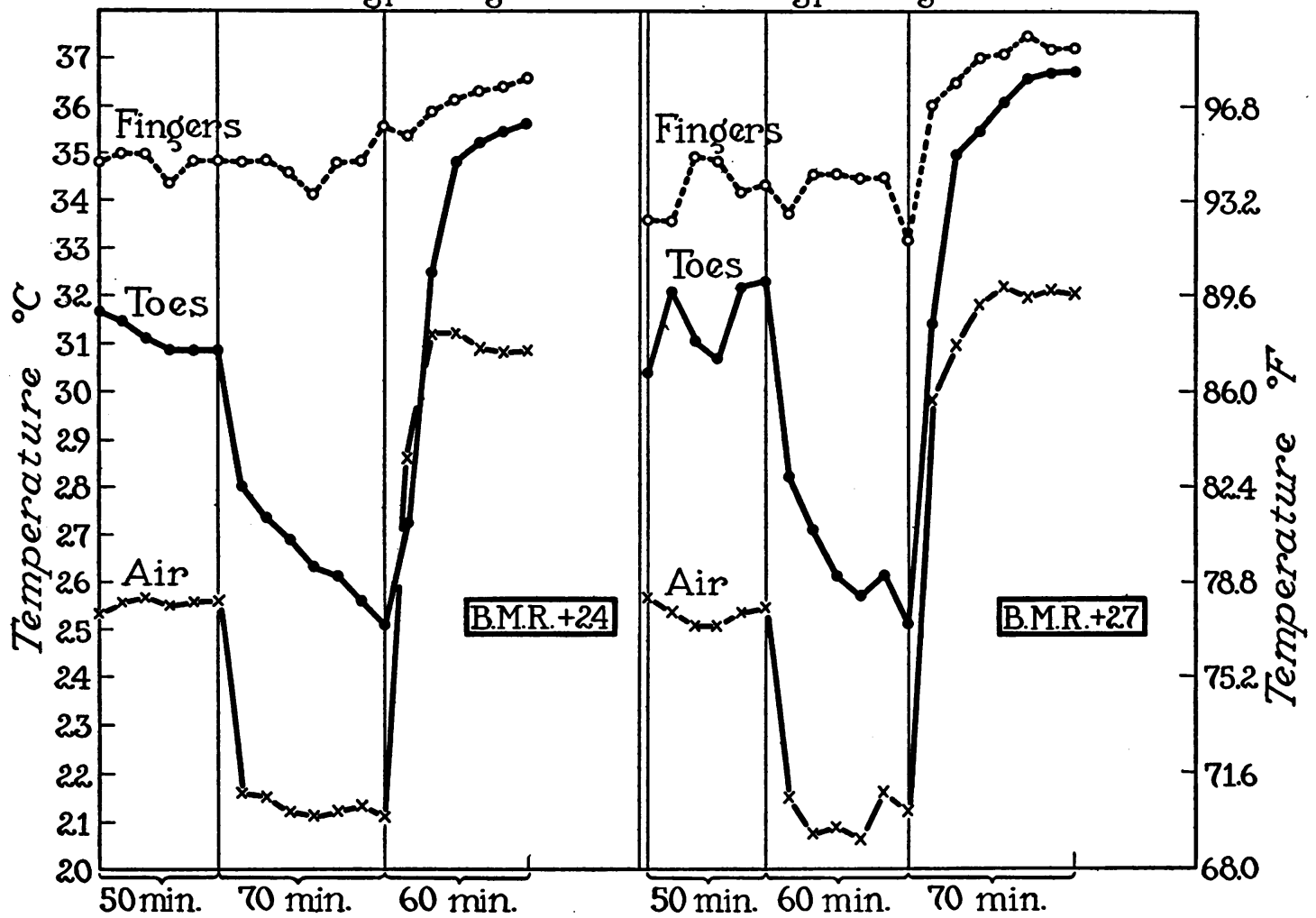

Fig. 4. A Comparison of the Changes of Skin Temperatures of the Fingers and Toes of a Subject with Changes of Environmental Temperatures During Induced Thiamine Deficiency and Induced HyperthyroidISM AND ONE WITH HYPERTHYROIDISM ONLY

\section{SUMMARY}

Under controlled environmental, postural, and metabolic conditions, none of the subjects of induced thiamine, riboflavin, or vitamin B complex deficiency showed any degree of vasomotor disturbance as evidenced by measurements of skin temperature and determination of rates of cooling and warming of body tissue.

When due consideration was given to the basal metabolic rate, the skin temperatures of the extremities under varying conditions were within the normal range. Furthermore, skin temperatures of the extremities of these subjects, measured at the height of the state of deficiency and following the administration of vitamins, showed a closer correlation with the basal metabolic rate than with the state of vitamin deficiency.

\section{BIBLIOGRAPHY}

1. Wenckebach, K. F., Das Beriberi-Herz: Morphologie, Klinik, Pathogenese. Pathologie und Klinik in Einzeldarst. Julius Springer, Berlin, 1934, Vol. 6, 106 pp.
2. Weiss, S., and Wilkins, R. W., Disturbance of the cardiovascular system in nutritional deficiency. J.A.M.A., 1937, 109, 786.

3. Wilkins, R. W., and Kolb, L. C., Vasomotor disturbances in peripheral neuritis. Am. J. M. Sc., 1941, 202, 216.

4. Williams, R. D., Mason, H. L., Power, M. H., and Wilder, R. M., Induced thiamine (vitamin $B_{1}$ ) deficiency in man; relation of depletion of thiamine to development of biochemical defect and of polyneuropathy. Arch. Int. Med., 1943, 71, 38.

5. Williams, R. D., Mason, H. L., Cusick, P. L., and Wilder, R. M., Observations on induced riboflavin deficiency and the riboflavin requirement of man. J. Nutrition, 1943, 25, 361.

6. Williams, R. D., Mason, H. L., and Wilder, R. M., The minimum daily requirement of thiamine of man. J. Nutrition, 1943, 25, 71.

7. Sheard, C., Williams, M. M. D., Roth, G. M., and Horton, B. T., The rôle of the extremities in the dissipation of heat from the body in various atmospheric and physiological conditions. Tr. Am. Soc. Heat. \& Vent. Eng., 1939, 45, 135.

8. Sheard, C., and Williams, M. M. D., Skin temperatures of the extremities and basal metabolic rates in individuals having normal circulation. Proc. Staff Meet., Mayo Clin., 1940, 15, 758. 